\title{
Effect of 11CFT and 11C33 inoculants on the chemical and fermentation composition, and aerobic stability of corn silage during the feed out period
}

\author{
Efeito dos inoculantes 11CFT e 11C33 sobre a \\ composição químico-fermentativa e estabilidade \\ aeróbia da silagem de milho durante o período de \\ utilização da silagem
}

\begin{abstract}
Tânia Mara Becher Ribas ${ }^{1}$; Mikael Neumannn'; Egon Henrique Horst ${ }^{3 *}$; Fernando
Braga Cristo 4; Edelmir Silvio Stadler Junior ${ }^{1 ;}$ Giovanna Bobato Pontorolo ${ }^{4}$; Fernando de Souza Sidor ${ }^{4}$; Daniel Corrêa Plodoviski'; ${ }^{5}$ Milena Pontarolo Machado ${ }^{5}$
\end{abstract}

\section{Highlights}

Bacterial inoculants improved the in situ digestibility of corn silage.

Bacterial inoculants caused no variations in temperature and $\mathrm{pH}$ at silage unloading.

L. buchneri, L. plantarum and E. faecium provided better aerobic stability.

\begin{abstract}
The objective was to evaluate the efficiency of two bacterial inoculants, 11CFT and 11C33, with different genera of lactic acid bacteria on the chemical and fermentation composition of the silage, and the temperature and $\mathrm{pH}$ behavior of the silage during the feed out period. The experimental design used was randomized blocks, with three treatments: corn silage without inoculant (control); corn silage with 11CFT inoculant (consisting of strains of Lactobacillus buchneri and L. casei); and corn silage with 11C33 inoculant (consisting of strains of L. buchneri, L. plantarum and Enterococcus faecium). The use of both inoculants increased the concentration of lactic acid in the silage $\left(22.42 \mathrm{~g} \mathrm{~kg}^{-1}\right.$ for control against 36.00 and $33.33 \mathrm{~g} \mathrm{~kg}^{-1}$ for $11 \mathrm{CFT}$ and 11C33, respectively) and reduced aerobic dry matter losses. The silage treated with 11C33 obtained a higher concentration of acetic acid $\left(17.44 \mathrm{~g} \mathrm{~kg}^{-1}\right)$ and propionic acid $\left(2.08 \mathrm{~g} \mathrm{~kg}^{-1}\right)$. The $11 \mathrm{CFT}$

1 Mestres em Ciências Veterinárias, Universidade Estadual do Centro-Oeste, UNICENTRO, Guarapuava, PR, Brasil. E-mail: taniamarabecherribas@hotmail.com; edelmirjunior@hotmail.com

2 Prof., Departamento de Medicina Veterinária, UNICENTRO, Guarapuava, PR, Brasil. E-mail: neumann.mikael@hotmail.com

${ }^{3}$ Discente de Doutorado em Ciência Animal, Universidade Estadual de Londrina, UEL, Londrina, PR, Brasil. E-mail: egonhh@yahoo.com.br

${ }^{4}$ Discentes de Mestrado em Ciências Veterinárias, UNICENTRO, Guarapuava, PR, Brasil. E-mail: fernandobragacristo@ gmail.com; giovannabpontarolo@hotmail.com; fernandosidor@gmai.com

${ }_{5}$ Discentes de Graduação em Medicina Veterinária, UNICENTRO, Guarapuava, PR, Brasil. E-mail: plodoviski@gmail.com; milenapontarolo98@hotmail.com

* Author for correspondence
\end{abstract}

Received: June 25, 2020 - Approved: Aug, 31, 2020 
inoculant provided a lower concentration of ethanol, however, without differing from the silage with 11C33 ( 0.70 and $1.61 \mathrm{~g} \mathrm{~kg}^{-1}$, respectively). Even without variations in temperature and $\mathrm{pH}$ at silage unloading, the use of the $11 \mathrm{C} 33$ inoculant generated a higher concentration of acetic and propionic acid, providing better aerobic stability days after unloading. Both inoculants also improved the in situ ruminal digestibility of corn silage compared to control silage. They provide an increase in the content of lactic and propionic acids, which assist to reduce dry matter losses and ethanol production. There were no variations in temperature and $\mathrm{pH}$ at the silo unloading, however, the use of the 11C33 inoculant generated a higher concentration of acetic and propionic acids providing better aerobic stability after exposure to air.

Key words: Organic acids. Lactic acid bacteria. Lactobacillus buchneri. L. plantarum. Dry matter losses.

\section{Resumo}

Objetivou-se avaliar a eficiência de dois inoculantes bacterianos, 11CFTe 11C33, com diferentes gêneros de bactériasácido láticas sobre a composição químico-fermentativa da silagem, bem como o comportamento da temperatura e $\mathrm{pH}$ da silagem durante sua utilização para alimentação. O delineamento experimental utilizado foi o de blocos casualizados, composto por três tratamentos: silagem de milho sem inoculante (controle); silagem de milho com inoculante 11CFT (constituído por cepas de Lactobacillus buchneri e L. casei); e silagem de milho com inoculante 11C33 (constituído por cepas de L. buchneri, L. plantarum e Enterococcus faecium). A utilização de ambos inoculantes aumentou a concentração de ácido lático da silagem $(22,42 \mathrm{~g}$ $\mathrm{kg}^{-1}$ para controle contra 36,00 e 33,33 $\mathrm{g} \mathrm{kg}^{-1}$ para 11CFT e 11C33, respectivamente) e reduziram as perdas de matéria seca em aerobiose. A silagem tratada com 11C33 obteve maior concentração de ácido acético $\left(17,44 \mathrm{~g} \mathrm{~kg}^{-1}\right)$ e propiônico $\left(2,08 \mathrm{~g} \mathrm{~kg}^{-1}\right)$. O inoculante 11CFT proporcionou menor concentração de etanol, porém, sem diferir da silagem com 11C33 (0,70 e 1,61 g kg-1, respectivamente). Mesmo sem haver variações de temperatura e $\mathrm{pH}$ no momento da desensilagem, o uso do inoculante 11C33 gerou maior concentração de ácido acético e propiônico proporcionando melhor estabilidade aeróbia após a desensilagem. Ambos inoculantes também melhoraram a digestibilidade in situ da silagem de milho em comparação com a silagem controle. Eles proporcionam aumento no teor dos ácidos lático e propiônico, que auxiliaram na redução das perdas de matéria seca e produção de etanol. Não ocorreram variações de temperatura e pH logo após abertura do silo, porém, o uso do inoculante 11C33 gerou uma maior concentração de ácidos acético e propiônico proporcionando melhor estabilidade aeróbia após a exposição ao ar.

Palavras-chave: Ácidos orgânicos. Bactéria ácido lática. Lactobacillus buchneri. L. plantarum. Perdas de matéria seca.

\section{Introduction}

The principle of silage fermentation involves the production of organic acids, primarily acetic and lactic acid, through the metabolization of soluble carbohydrates by lactic acid bacteria in an anaerobic environment (Jobim \& Nussio, 2013). At first, there is the production of acetic acid by heterofermentative bacteria, which has a primary function in controlling molds and yeasts after opening the silo and exposing the silage to air. This group of bacteria can be subdivided into obligate and facultative (Holzer, Mayrhuber, Danner, \& Braun, 2003), the former uses hexoses for the production of lactic and/ 
or acetic acid, and pentoses for the production of acetic acid, exclusively. Facultative bacteria can produce both acids from hexoses and pentoses, depending on the final electron receptor.

Namely, lactic acid is considered a strong acid responsible for stabilizing the $\mathrm{pH}$ of the ensiled forage and controlling spoilage bacteria (Tabacco, Piano, Revello-Chion, \& Borreani, 2011). However, the faster the stabilization of this $\mathrm{pH}$, the lower the control of fungi and yeasts by acetic acid, which can culminate in a silage with low aerobic stability, which is the main reason why the use of homofermentative bacteria strains is restricted in inoculants (Lynch, Baah, \& Beauchemin, 2015).

The production of commercial bacterial inoculants comprises mostly blends of species of lactic acid bacteria, in which Lactobacillus plantarumisthemostcommonlyused, and often Lactobacillus casei, Lactobacillus buchneri, in addition to other species such as Pediococcus faecium and Enterococcus faecium (Muck, 2010). The main function of these inoculants is to promote higher concentrations of organic acids during fermentation (M. S. J. Silva, Jobim, Poppi, Tres, \& Osmari, 2015); however, it is important to consider that inoculants with different combinations of bacteria have different functions and provide different results (M. R. Oliveira, Neumann, Oliboni, Gobetti, \& Faria, 2011). In a meta-analysis, A. S. Oliveira et al. (2017) concluded that the use of inoculants with lactic acid bacteria can improve the chemical and fermentation characteristics, decrease losses of dry matter and nutrients in corn silages. However, the authors warn that different combinations of bacteria provide different results.
In this context, the goal of this study was to evaluate the efficiency of two bacterial inoculants with different genera of lactic acid bacteria on the chemical and fermentation composition of the silage, as well as the temperature and $\mathrm{pH}$ behavior of the silage during the feed out period.

\section{Material and Methods}

The experiment was conducted in the Laboratory of Food Analysis and Nutrition of Ruminants and in the Didactic unit for research and extension in Beef Cattle - Confinement of the Animal Production Center (NUPRAN) along with the Master's degree Program in Veterinary Sciences of the Agricultural and Environmental Sciences Sector, State University of the Midwest (CEDETEG/UNICENTRO), located in Guarapuava, State of Paraná, Brazil $\left(25^{\circ} 23^{\prime} 02\right.$ "S and 51०29'43" W).

For making the silage, the corn hybrid $\mathrm{P}$ $2866 \mathrm{H}$ was harvested at the hard-grain stage and chopped with a Pecus 9004 machine (Nogueira), set to $15 \mathrm{~mm}$ sting size. The inoculants were diluted in water, according to the manufacturer's instructions, to obtain a concentration of $20 \times 1010 \mathrm{CFU} \mathrm{g}^{-1}$ of the product per ton of fresh biomass, using a variable pressure sprayer. The application was made during the corn harvest, using a spray nozzle located in the unloading chute of the forage machine, seeking a uniform distribution of the product.

The experimental design used was randomized blocks, with three treatments: $T_{1}$ : corn silage without inoculant (control); $T_{2}$ : corn silage with Pioneer ${ }^{\circledR} 11 \mathrm{CFT}$ inoculant (strains of Lactobacillus buchneri $\left[1.1 \times 10^{11} \mathrm{CFU} \mathrm{g}^{-1}\right]$ and 
Lactobacillus casei $\left.\left[1.1 \times 10^{11} \mathrm{CFU} \mathrm{g^{-1 }}\right]\right)$; and $\mathrm{T}_{3}$ : corn silage with Pioneer ${ }^{\circledR} 11 \mathrm{C} 33$ inoculant (strains of Lactobacillus buchneri [1.1 $\times 10^{11}$ CFU g $\left.{ }^{-1}\right]$, Lactobacillus plantarum $\left[1.1 \times 10^{11}\right.$ CFU g-1] and Enterococcus faecium $\left[1 \times 10^{10}\right.$ CFU g $\left.{ }^{-1}\right]$ ), and four repetitions each, where each repetition was represented by a storage silo.

Experiment 1. Dry matter losses, chemical and fermentation composition and in situ digestibility

The forage collected from each treatment was stored in trench silos $15 \mathrm{~m}$ long, $4 \mathrm{~m}$ wide and $1.2 \mathrm{~m}$ high, sealed with silage tarp double side of polyethylene $(150 \mu \mathrm{m})$. The opening of the silos occurred simultaneously at 160 days after sealing. During the ensiling, eight bags of malleable nylon $100 \%$ polyamine, with $85 \mu \mathrm{m}$ pores and $12 \times 50 \mathrm{~cm}$ in size, containing silage were randomly allocated inside each silo. Each bag was identified, weighed individually empty, and weighed again after filling. Nylon clamps were used to seal the bags. After the removal of each bag, it was weighed and dry matter was measured, and this procedure allowed to estimate the DM losses from silage.

Daily, at 07h30 and 16h30, temperature was measured in silages of the different treatments at three points at the top layer and three points at the bottom layer of each silo using a metal rod digital thermometer, as well as the ambient temperature. The temperature measurements in the silage, in the referred strata, were carried out at a depth of $7 \mathrm{~cm}$ in the structured mass at the silo face. In the same period, $\mathrm{pH}$ was read by removing the silage for use in animal feed, through a digital potentiometer.
Silo unloading was divided in four periods of evaluation, three periods of 28 days and the fourth with 21 days. The extraction of silage from each silo to feed the animals occurred with a daily advance of $15 \mathrm{~cm}$. Homogeneous silage samples were collected in these different evaluation periods, weighed and pre-dried in an air forced oven at $55^{\circ} \mathrm{C}$ to constant weight, for analysis of partial dry matter (DM) content, being sequentially ground in a Willey mill, with a $1 \mathrm{~mm}$ mesh sieve. The pre-dried samples were analyzed for total dry matter in an oven at $105^{\circ} \mathrm{C}$ for 4 hours, crude protein (CP) by the micro Kjeldahl method, and the mineral matter (MM) by incineration at 550 ${ }^{\circ} \mathrm{C}$ for 4 hours. The contents of neutral detergent fiber (NDF), acid detergent fiber (ADF) and lignin (LIG) were determined according to Silva and Queiroz (2009).

The dry matter digestibility of the materials was estimated by the in situ technique using nylon bags with $12 \times 8 \mathrm{~cm}$ in size and $40-60 \mu \mathrm{m}$ pores, containing $5 \mathrm{~g}$ dry sample of each material milled to $1 \mathrm{~mm}$, for later incubation in the rumen. The incubation times used were 24 and 48 hours in two steers with 36 months of age, average body weight of $550 \mathrm{~kg}$, with permanent ruminal fistula.

The concentration of lactic acid was determined according to the methodology described by Price (1969). The concentrations of ethanol, and acetic, propionic, butyric, valeric and isovaleric acids in the samples were determined by gas chromatography using a Shimadzu ${ }^{\circledR}$ GC-2010 Plus chromatograph equipped with an AOC-20i auto injector, Stabilwax-DA ${ }^{\mathrm{TM}}$ capillary column $(30 \mathrm{~m}, 0.25$ $\mathrm{mm} I \mathrm{D}, 0.25 \mu \mathrm{m} \mathrm{df}$ Restek $^{\circledR}$ ) and flame ionization detector (FID), after acidification with $1 \mathrm{M}$ phosphoric acid p.a. (Ref. 100573, Merck $^{\circledR}$ ) and 
fortification with the WSFA-2 standard (Ref. 47056, Supelco ${ }^{\circledR}$ ). The sample collected was $15 \mathrm{~g}$ and was homogenized in a blender with $200 \mathrm{~mL}$ distilled water. After homogenizing for one minute, the sample was sieved and centrifuged, a volume of $1 \mu \mathrm{L}$ was taken. This sample was injected at a 40:1 split ratio, using helium as carrier gas at a flow rate of $42 \mathrm{~cm}$ $\mathrm{s}^{-1}$, obtaining the separation of the analyses in a chromatographic run of 11.5 minutes. The injector and detector temperatures were $250^{\circ} \mathrm{C}$ and $300^{\circ} \mathrm{C}$, respectively, and the initial column temperature was $40^{\circ} \mathrm{C}$. The column temperature ramp started with a gradient from 40 to $120^{\circ} \mathrm{C}$ at a rate of $40^{\circ} \mathrm{C} \mathrm{min}{ }^{-1}$, followed by a gradient from 120 to $180^{\circ} \mathrm{C}$ at a rate of $10^{\circ} \mathrm{C} \mathrm{min}{ }^{-1}$, and from 180 to $240^{\circ} \mathrm{C}$ at a rate of $120^{\circ} \mathrm{C} \mathrm{min}^{-1}$, keeping the temperature at 240 ${ }^{\circ} \mathrm{C}$ for another 3 minutes at the end. For the quantification of analytes, a calibration of the method was made with dilutions of the WSFA-2 standard (Ref. 47056, Supelco ${ }^{\circledR}$ ), glacial acetic acid (Ref. 33209, Sigma-Aldrich ${ }^{\odot}$ ) and HPLC grade ethanol (Ref. 459828, Sigma-Aldrich ${ }^{\circledR}$ ) analyzed under the conditions described above. The detection and integration of the peaks were made using the GCsolution 2.42.00 software (Shimadzu ${ }^{\circledR}$ ).

\section{Experiment 2. Aerobic stability}

Aerobic stability assessments were performed twice during the silo unloading period. The first evaluation was carried out 40 days after opening the silos and the second, 83 days after opening the silo. The silage of each silo was loosened to facilitate the exposure of the ensiled material to air, and a $400 \mathrm{~g}$ sample of the material was placed in buckets with a capacity of $1 \mathrm{~kg}$. The buckets were stored in a controlled environment, with a temperature set to remain stable at $25{ }^{\circ} \mathrm{C}$, throughout the evaluation period. To determine aerobic stability, daily at $06 \mathrm{~h} 00,14 \mathrm{hOO}$ and $22 \mathrm{~h} 00$ hours, temperature and $\mathrm{pH}$ were read and contents of dry matter and mineral matter of the evaluated silages were determined. The evaluation time was maintained until the loss of aerobic stability of the material.

The silage temperature was measured with a digital long-stemmed thermometer model Gulterm 1001 inserted at the center of the forage mass. The $\mathrm{pH}$ readings were measured using a digital potentiometer. In a second set of buckets, samples were taken daily, weighed, and pre-dried in a forced-air oven at $50^{\circ} \mathrm{C}$ to constant weight to determine the partial dry matter content, sequentially ground in a Willey mill, with a $1 \mathrm{~mm}$ mesh sieve. In the ground samples, the contents of dry matter (DM) and mineral matter (MM) were determined, according to Silva and Queiroz (2009). The criterion for defining aerobic stability break was considered when the $\mathrm{pH}$ increased in levels above 0.5 units in up to five days of evaluation, as mentioned by Weinberg et al. (2007). The aerobic stability of corn silages treated with different inoculants, at different times of silo unloading ( 40 and 83 days), was promoted by the evaluation of the final contents of dry matter and mineral matter, as well as by the time to achieve maximum temperature and increase of $\mathrm{pH}$.

\section{Statistical analysis}

Data related to dry matter losses, the chemical and fermentation composition and in situ digestibility of DM, as well as the average contents of dry matter and mineral matter, and 
$\mathrm{pH}$ in each evaluation periods of the different silages were subjected to the Shapiro-Wilk and Bartlett tests to check the assumptions of normality and homogeneity of variance, respectively. Once these assumptions were met, the F-test was applied at 5\% probability of confidence, by analysis of variance (ANOVA) and then the Tukey's test to compare multiple means at $5 \%$ significance. The temperature and $\mathrm{pH}$ data were also subjected to polynomial regression analysis, considering the variable hours of evaluation, using the PROCREG procedure of SAS software (1993).

\section{Results and Discussion}

The use of inoculant was not able to cause differences regarding the contents of dry matter, mineral matter, crude protein, acid detergent fiber and lignin, with average values of $38.82 \%, 2.40 \%, 5.86 \%, 26.74 \%$ and $4.70 \%$, respectively (Table 1), regardless the time the material remained ensiled. The fiber content in neutral detergent was higher for silage inoculated with $11 \mathrm{C} 33$ (46.72\%), while the control and silage inoculated with 11CFT did not differ from each other (41.00 and $43.17 \%$, respectively). The $24 \mathrm{~h}-\mathrm{DMD}$ of silage was not affected by the use of inoculants, with an average of $54.47 \%$. However, the 48 h-DMD of both treated silages was higher compared to the control silage. Fugita et al. (2012) and Abdel-Rahman, Tashiro and Sonomoto (2011) explained that the performance of some enzymes produced by lactic acid bacteria facilitate the use of fiber, proving that higher fiber content in food is not synonymous with less digestibility.

Both inoculants resulted in lower levels of drymatter lossinanaerobiosis, indicating that the greater and more accelerated production of lactic acid has reduced the concentration of spoilage aerobic microorganisms in the aerobic phase that precedes the stabilization after silo sealing. According to Borreani, Tabacco, Schmidt, Holmes and Muck (2018), facultative heterofermentative bacteria, such as $L$. casei and $L$. plantarum, are justified by the lactic acid-producing capacity and markedly lowering the $\mathrm{pH}$ of the ensiled mass.

Kleinschmit and Kung (2006) showed that the isolated use of $L$. buchneri increased dry matter losses. Likewise, Filya and Sucuc (2010) found greater losses of dry matter with the isolated use of $L$. buchneri, while the use of $L$. plantarum reduced the losses. The inoculants in this study are facultative and obligate heterofermentative bacteria combinations, leading to greater benefits (A. S. Oliveira et al., 2017). Rabelo et al. (2012) also evaluated the effects of combinations of inoculants with facultative heterofermentative bacteria in corn silage and found that the use of all contributed to the reduction of dry matter losses. 
Table 1

Chemical composition, in situ ruminal digestibility and dry matter losses of corn silage treated with different bacterial inoculants

\begin{tabular}{|c|c|c|c|c|c|c|}
\hline \multirow{2}{*}{ Parameter } & \multicolumn{3}{|c|}{ Silage } & \multirow{2}{*}{ Average } & \multirow{2}{*}{$P$-value } & \multirow{2}{*}{ SEM } \\
\hline & Control & $11 \mathrm{CFT}$ & $11 \mathrm{C33}$ & & & \\
\hline $\mathrm{DM}, \%$ & 39.00 & 40.11 & 39.45 & 38.82 & 0.9246 & 1.2528 \\
\hline $\mathrm{MM}, \%$ & $2.49 a$ & $2.23 b$ & $2.50 \mathrm{a}$ & 2.40 & 0.0354 & 0.0750 \\
\hline $\mathrm{CP}, \%$ & 5.82 & 5.57 & 6.21 & 5.86 & 0.1963 & 0.2385 \\
\hline aNDF, \% & $41.00 \mathrm{~b}$ & $43.17 b$ & $46.72 \mathrm{a}$ & 43.63 & 0.0073 & 1.5005 \\
\hline$A D F, \%$ & 27.36 & 25.87 & 27.02 & 26.74 & 0.5749 & 1.0326 \\
\hline LIG, \% & 4.83 & 4.49 & 4.79 & 4.70 & 0.7329 & 0.3327 \\
\hline $24 \mathrm{~h}-\mathrm{DMD}, \%$ & 56.67 & 54.71 & 52.05 & 54.47 & 0.3242 & 2.0951 \\
\hline 48h-DMD, \% & $59.94 b$ & $68.86 a$ & $65.64 a$ & 64.81 & 0.0002 & 1.1297 \\
\hline Dry matter losses, \% & $9.62 \mathrm{a}$ & $5.33 b$ & $4.74 \mathrm{~b}$ & 6.63 & 0.0463 & 2.0785 \\
\hline
\end{tabular}

Averages, followed by different letters in the same row, differ by the Tukey Test at $5 \%$.

Along with lower dry matter losses, the silages inoculated with 11CFT and $11 \mathrm{C} 33$ also showed a higher concentration of lactic acid in their composition (36.00 and $33.33 \mathrm{~g} \mathrm{~kg}^{-1}$, respectively; Table 2). The high concentration of lactic acid stimulates the drop in $\mathrm{pH}$ accelerating the stability of the silage (Jobim \& Nussio, 2013). However, after opening the silo, lactic acid becomes a readily available substrate for yeasts, enhancing their development and nutrient consumption, providing a silage with low aerobic stability (Wilkinson \& Davies, 2013). These indicate the importance of an assertive combination of bacteria in the inoculant, since the production of acetic acid to control yeasts after opening is fundamental. The 11C33 inoculant produced a silage with a greater participation of acetic acid (17.44 $\mathrm{g} \mathrm{kg}^{-1}$ ) compared to the other treatments. 
Table 2

Fermentation profile $\left(\mathrm{g} \mathrm{kg}^{-1}\right)$ of corn silage treated with different bacterial inoculants

\begin{tabular}{|c|c|c|c|c|c|c|}
\hline \multirow{2}{*}{ Parameter } & \multicolumn{3}{|c|}{ Silage } & \multirow{2}{*}{ Average } & \multirow{2}{*}{$P$-value } & \multirow{2}{*}{ SEM } \\
\hline & Control & $11 \mathrm{CFT}$ & $11 \mathrm{C33}$ & & & \\
\hline \multicolumn{7}{|c|}{$\mathrm{g} \mathrm{kg}^{-1}$ de DM } \\
\hline Latic Acid & $22.42 b$ & $36.00 \mathrm{a}$ & $33.33 a$ & 30.58 & 0.0001 & 0.6560 \\
\hline Acetic Acid & $11.49 b$ & $9.63 \mathrm{~b}$ & $17.44 \mathrm{a}$ & 12.85 & 0.0036 & 0.6712 \\
\hline Propionic Acid & $0.22 \mathrm{c}$ & $1.22 \mathrm{~b}$ & $2.08 \mathrm{a}$ & 1.18 & 0.0001 & 0.0686 \\
\hline Isobutyric Acid & $0.00 \mathrm{~b}$ & $0.24 a$ & $0.06 \mathrm{~b}$ & 0.10 & 0.0001 & 0.0097 \\
\hline Butyric Acid & $0.06 \mathrm{~b}$ & $0.27 a$ & $0.14 a b$ & 0.16 & 0.0237 & 0.2455 \\
\hline Isovaleric Acid & $0.00 \mathrm{c}$ & $0.18 a$ & $0.10 \mathrm{~b}$ & 0.09 & 0.0001 & 0.0073 \\
\hline Valeric Acid & $0.00 \mathrm{~b}$ & $0.31 \mathrm{a}$ & $0.09 \mathrm{~b}$ & 0.13 & 0.0023 & 0.0242 \\
\hline Ethanol & $1.81 \mathrm{a}$ & $0.70 \mathrm{~b}$ & $1.61 \mathrm{ab}$ & 1.37 & 0.0300 & 1.4376 \\
\hline
\end{tabular}

Averages, followed by different letters in the same row, differ by the Tukey Test at $5 \%$.

Ethanol is basically produced by aerobic microorganisms, and yeasts play a key role in this production (Montes, Hafner, Rotz, \& Mitloehner, 2010). The concentration of ethanol found in the 11CFT treatment was 0.70 $\mathrm{g} \mathrm{kg}^{-1}$, however it did not differ from the $11 \mathrm{C} 33$ treatment $\left(1.61 \mathrm{~g} \mathrm{~kg}^{-1}\right)$. In review, Zopollatto et al. (2009) verified that the use of lactic acid-producing bacteria in silages of various forages stimulated the production of ethanol, and suggest that these results are due to less control of yeasts.

The control treatment obtained the lowest concentration of propionic acid $(0.22$ $\mathrm{g} \mathrm{kg}^{-1}$ ) compared to treatments 11CFT (1.28 $\left.\mathrm{g} \mathrm{kg}^{-1}\right)$ and $11 \mathrm{C} 33\left(2.08 \mathrm{~g} \mathrm{~kg}^{-1}\right)$, given that the production of lactic acid was lower in this silage, and according to Moon (1983), bacteria producing propionic acid consume lactic acid to produce propionate, acetate and carbon dioxide. It is noteworthy that propionic acid is an important antifungal, which can improve the aerobic stability of the silage.

The control silage, in turn, showed the lowest concentration of butyric acid compared to both inoculated silages. According to Sá, Nussio, Zopollatto, Junges and Bispo (2013), high concentrations of butyric acid denote that there was an action of enterobacteria during the fermentation process, and a greater availability of nutrients present in the inoculated silages may have facilitated the development of these spoilage microorganisms.

Table 3 lists the average data of dry matter, mineral matter and $\mathrm{pH}$ during the period of 105 days of use of silages for animal feed. The dry matter contents remained stable both between silages and in different periods of silo unloading. The contents of mineral matter, regardless of the evaluation period, also showed no differences. 
Table 3

Average contents of dry matter, mineral matter and pH during 105 days in feed out period

\begin{tabular}{|c|c|c|c|c|}
\hline \multirow{2}{*}{$\begin{array}{l}\text { Evalueted } \\
\text { periods }\end{array}$} & \multicolumn{3}{|c|}{ Silage } & \multirow{2}{*}{ Average } \\
\hline & Control & $11 \mathrm{CFT}$ & $11 \mathrm{C33}$ & \\
\hline & \multicolumn{4}{|c|}{ Dry matter, \% in NM } \\
\hline 0 to 28 days & 42.13 & 40.75 & 41.50 & 41.46 \\
\hline 29 to 56 days & 38.91 & 39.84 & 40.60 & 39.79 \\
\hline 57 to 84 days & 40.29 & 39.10 & 40.84 & 40.08 \\
\hline 85 to 105 days & 42.37 & 41.07 & 38.02 & 40.47 \\
\hline \multirow[t]{2}{*}{ Average } & 40.81 & 40.19 & 40.24 & \\
\hline & \multicolumn{4}{|c|}{ Mineral matter, \% in DM } \\
\hline 0 to 28 days & 3.06 & 3.19 & 2.62 & $2.96 \mathrm{~B}$ \\
\hline 29 to 56 days & 3.15 & 3.16 & 2.70 & $3.00 \mathrm{~B}$ \\
\hline 57 to 84 days & 2.35 & 2.32 & 2.77 & $2.48 \mathrm{~B}$ \\
\hline 85 to 105 days & 3.75 & 4.68 & 4.54 & $4.32 \mathrm{~A}$ \\
\hline \multirow[t]{2}{*}{ Average } & 3.08 & 3.34 & 3.16 & \\
\hline & \multicolumn{4}{|c|}{$\mathrm{pH}$, index } \\
\hline 0 to 28 days & 3.95 & 3.98 & 4.13 & $4.02 \mathrm{~B}$ \\
\hline 29 to 56 days & 4.00 & 3.90 & 4.02 & $3.97 \mathrm{~B}$ \\
\hline 57 to 84 days & 4.05 & 3.97 & 4.85 & $4.29 \mathrm{~A}$ \\
\hline 85 to 105 days & 4.54 & 4.35 & 4.45 & $4.44 \mathrm{~A}$ \\
\hline Average & $4.13 \mathrm{~b}$ & $4.05 b$ & $4.36 a$ & \\
\hline
\end{tabular}

Averages, followed by different letters in the same row, differ by the Tukey Test at 5\%.

Regarding the evaluated periods, the dry matter and the temperature of the silage exposed to air were not affected. The mineral content of the silage was higher $(P>0.05)$ in the last evaluated periods, which may be related to the longer time of exposure to the environment and greater consumption of soluble nutrients by the microorganisms and the acids themselves, which result in consumption and hydrolysis of carbohydrates and proteins, increasing the content of mineral matter.

Based on the data from the present study, the authors corroborate that, even with the use of inoculants, priority should be given to adequate handling of the silo face during unloading (Li \& Nishino, 2011). Rodrigues et al. (2015) also observed an increase in $\mathrm{pH}$ values in more advanced periods of silage use, given that the longer time of exposure to yeasts can contribute to greater consumption of lactic acid.

Table 4 lists the summary of the analysis of variance of data relating to temperature, $\mathrm{pH}$, dry matter and mineral content of corn silage treated with different inoculants, at different evaluated periods. 


\section{Table 4}

Summary of analysis of variance for temperature, $\mathrm{pH}$, dry matter and mineral matter contents of corn silage treated with different inoculants, at different feed out times

\begin{tabular}{|c|c|c|c|c|c|c|c|}
\hline \multirow{2}{*}{$\begin{array}{l}\text { Source of } \\
\text { mariation }\end{array}$} & \multicolumn{3}{|c|}{ Mean error square } & \multirow{2}{*}{$C V, \%$} & \multirow{2}{*}{ Average } & \multicolumn{2}{|c|}{ Probability } \\
\hline & Inoculant (I) & Block (B) & Error & & & I & B \\
\hline \multicolumn{8}{|l|}{$40^{\text {th }}$ day: } \\
\hline Temperature & 225.3137 & 16.2650 & 2.0430 & 5.56 & 25.71 & 0.0001 & 0.0006 \\
\hline $\mathrm{pH}$ & 13.3286 & 0.1752 & 0.1476 & 6.50 & 5.91 & 0.0001 & 0.3090 \\
\hline Dry matter & 0.0074 & 0.0011 & 0.0004 & 4.71 & 44.62 & 0.0001 & 0.0926 \\
\hline Mineral matter & 0.5465 & 0.0045 & 0.2115 & 19.00 & 2.42 & 0.0797 & 0.9790 \\
\hline \multicolumn{8}{|l|}{$83^{\text {th }}$ day: } \\
\hline Temperature & 226.7946 & 2.5900 & 2.1930 & 6.10 & 24.27 & 0.0001 & 0.3115 \\
\hline $\mathrm{pH}$ & 14.0102 & 1.2675 & 0.2119 & 10.15 & 4.53 & 0.0001 & 0.0036 \\
\hline Dry matter & 0.0030 & 0.0007 & 0.0004 & 3.88 & 49.26 & 0.0005 & 0.1319 \\
\hline Mineral matter & 0.4826 & 0.0629 & 0.3823 & 24.15 & 2.55 & 0.2878 & 0.8484 \\
\hline
\end{tabular}

The regression equations in Figure 1 show a quadratic trend for all silages in all evaluated periods. At 83 days (b), the silage inoculated with $11 \mathrm{C} 33$ showed the lowest temperatures at the end of the aerobic stability tests. At both times, silage with 11C33 showed a minimum point, while silage inoculated with $11 \mathrm{CFT}$ showed curves with a maximum point in both periods. It is explicit in the trend line at 83 days (a) the influence of the ambient temperature on the silage, given that the silage only reduced its temperature during the stability test.

Trends very close to those described for silage with 11CFT were observed in the control silage in all the evaluation periods, showing that the presence of a genus of lactic acid-producing bacteria (L. plantarum) can be the great differential brought by the $11 \mathrm{C} 33$ inoculant.
Data in figure 2 show that the regression equations for $\mathrm{pH}$, in the two different evaluated periods, had an increasing linear behavior with advancing hours of aerobic exposure. According to Rabelo et al. (2012), the increase in $\mathrm{pH}$ occurs due to the consumption of lactic acid by yeasts and also by the breakdown of proteins into ammonia nitrogen by fungi in a second moment. This breakdown of more complex structures, such as proteins, is described just after the beginning of the $\mathrm{pH}$ increase, and are responsible for the greatest nutritional losses in the food (Kleinschmit \& Kung, 2006).

As observed in the temperature behavior, silage with $11 \mathrm{C} 33$ inoculant also showed good control of $\mathrm{pH}$ increase at 83 days, while at 40 days the increase was prominent. As highlighted in the past, this silage presented greater differences in relation to the others, while the silage with 11CFT inoculant and control showed similar trends in all periods. 
a)

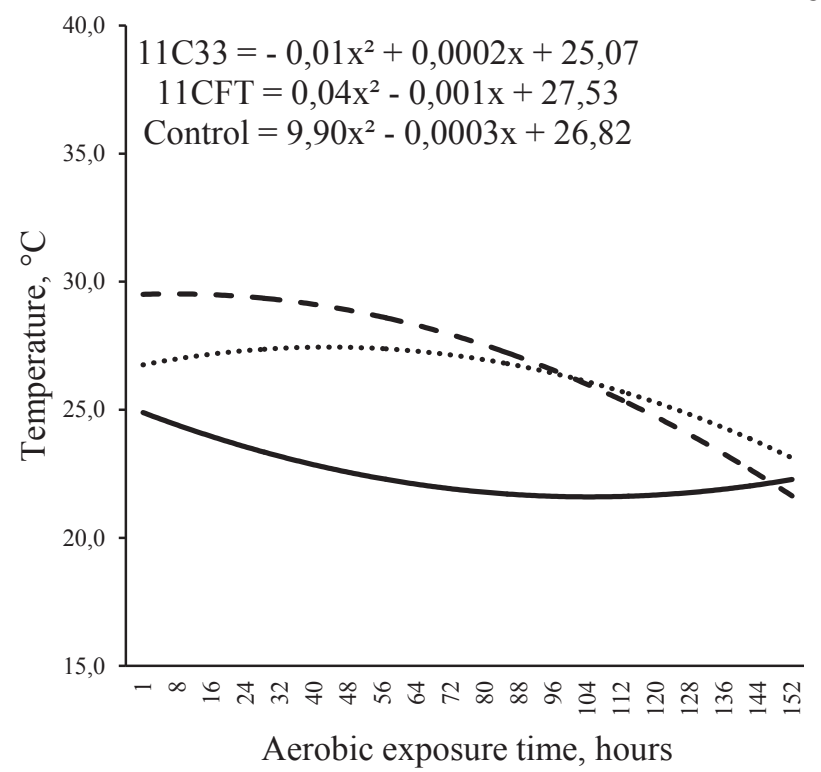

b)

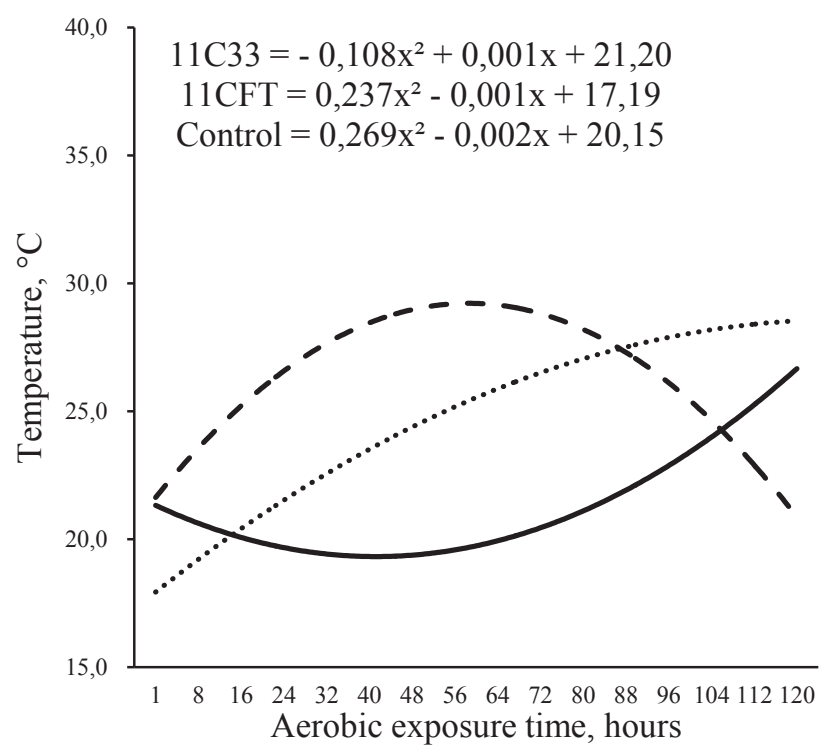

Figure 1. Temperature of corn silage treated with inoculants $11 \mathrm{C} 33$ (continuous line), 11CFT (dotted line), and control (dashed line), at $40^{\text {th }}$ day (a) and $83^{\text {th }}$ day (b) after opening the silo.

c)

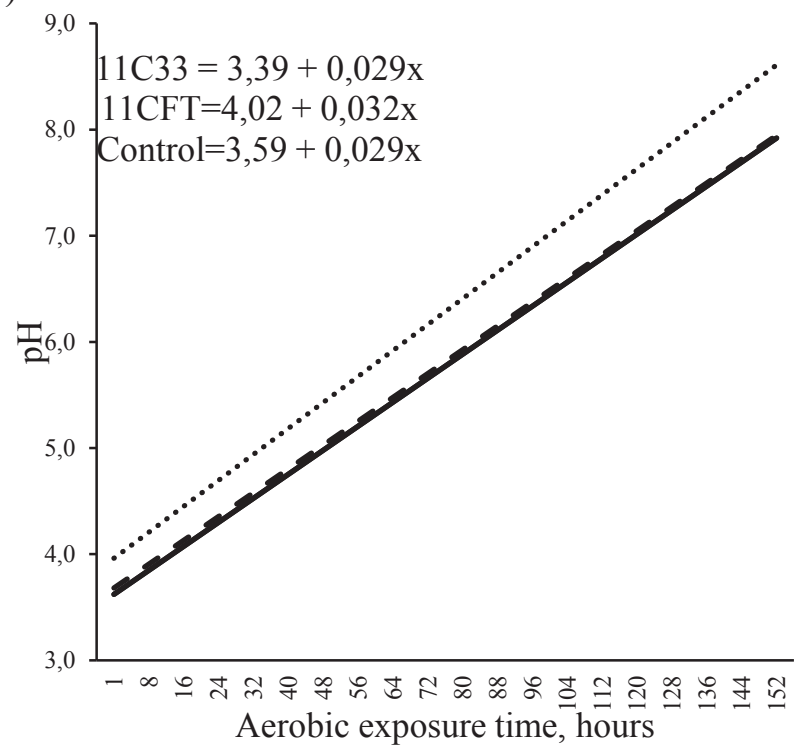

d)

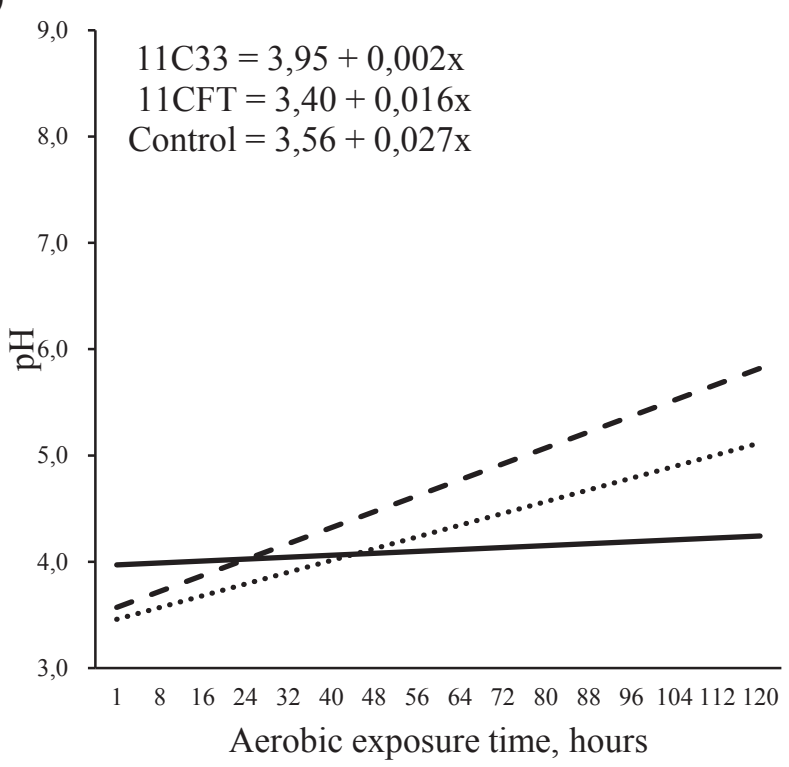

Figure 2. Values of $\mathrm{pH}$ of corn silage treated with inoculants 11C33 (continuous line), 11CFT (dotted line), and control (dashed line), at $40^{\text {th }}$ day (c) and $83^{\text {th }}$ day (d) after opening the silo. 
The largest increases in $\mathrm{pH}$ by time elapsed were observed for silage with 11CFT at 40 days $\left(0.032 \mathrm{pH}\right.$ points hour $\left.{ }^{-1}, \mathrm{f}\right)$, for control silage at 83 days $\left(0.027 \mathrm{pH}\right.$ points hour $\left.{ }^{-1}, \mathrm{~g}\right)$. The $\mathrm{pH}$ observed after the aerobic stability tests did not maintain the same trends in the different evaluation period (Table 5). There was no difference between the final $\mathrm{pH}$ of the silages used at 40 days of use. At 83 days, it is possible to notice that the silage with $11 \mathrm{C} 33$ inoculant showed the lowest $\mathrm{pH}$ in relation to the silage with 11CFT and control (4.3 against 6.1 and 6.2 , respectively).
Coincidentally, these data had relationships with the hours for loss of aerobic stability, where there was no difference in the first evaluation, but, in the second, the silage with 11CFT inoculant and control silage lost their stability with 96.0 and 80.0 hours, respectively, while the silage inoculated with 11C33 did not destabilize during the evaluation time. Therefore, the 11C33 inoculant proved to be more effective for aerobic stability.

\section{Table 5}

Aerobic stability of corn silages treated with different inoculants, at different feed out times $\left(40^{\text {th }}\right.$ and $83^{\text {th }}$ day)

\begin{tabular}{lcccc} 
& \multicolumn{3}{c}{ Silage } & P-value \\
\cline { 2 - 4 } & Control & $11 \mathrm{CFT}$ & $11 \mathrm{C} 33$ & \\
\hline 40 & & & & \\
Dry matter, \%NM & $38.76 \mathrm{~b}$ & $38.65 \mathrm{~b}$ & $39.60 \mathrm{a}$ & 0.0001 \\
\hline Mineral matter, \% DM & 2.28 & 2.42 & 2.41 & 0.0797 \\
\hline Stability after pH test & 7.7 & 8.2 & 7.6 & 0.5540 \\
\hline Time to maximum temperature, hours & $48.3 \mathrm{~b}$ & $80.0 \mathrm{a}$ & $32.0 \mathrm{~b}$ & 0.0001 \\
\hline Aerobic stability, hours & 40.0 & 40.0 & 48.0 & 0.2935 \\
\hline 83 & & & & \\
Dry matter, \% NM & $47.31 \mathrm{a}$ & $45.90 \mathrm{~b}$ & $40.09 \mathrm{c}$ & 0.0005 \\
\hline Mineral matter, \% MS & $2.45 \mathrm{a}$ & $2.45 \mathrm{a}$ & $2.48 \mathrm{a}$ & 0.2878 \\
\hline Stability after pH test & $6.2 \mathrm{a}$ & $6.1 \mathrm{a}$ & $4.3 \mathrm{~b}$ & 0.0226 \\
\hline Time to maximum temperature, hours & $48.0 \mathrm{c}$ & $80.0 \mathrm{~b}$ & $112.0 \mathrm{a}$ & 0.0001 \\
\hline Aerobic stability, hours & 80.0 & 96.0 & $\mathrm{ND}$ & -
\end{tabular}

Averages, followed by different letters in the same row,differ by the Tukey Test at $5 \%$.

ND: Loss of aerobic stability was not diagnosed during evaluation time.

A. S. Oliveira et al. (2017) evaluated aerobic stability in conventional silage $(40.09 \%$ dry matter) and inoculated (40.88\% dry matter) with Lactobacillus plantarum and Pediococcus acidilactici at a concentration of $1.0 \times 105$ CFU g ${ }^{-1}$, and obtained less aerobic stability in the inoculated wheat silage. Oney et al. (2018) when evaluating moisture difference in corn silage and Lactobacillus buchneri as inoculant found that the combination of the inoculant with the low silage moisture positively influenced aerobic stability. In the present study, the 
forage moisture content was also high, and only the 11C33 inoculant was superior; the other $11 \mathrm{CFT}$ inoculant may not have responded to stability due to the moisture content.

Table 5 also lists that there was no difference between the mineral content of silages, regardless of the evaluation period. In theory, when there is consumption of organic compounds, there is an increase in mineral matter in the silage (Valeriano et al., 2009; Zanette et al., 2012), and this behavior without difference implies that the use of inoculants did not interfere with the consumption of these organic compounds by spoilage microorganisms.

\section{Conclusions}

Both inoculants improved the in situ digestibility of corn silage compared to control silage. They provide an increase in the content of lactic and propionic acids, which assist to reduce dry matter losses and ethano production.

There were no variations in temperature and $\mathrm{pH}$ at the silo unloading, however, the use of the $11 \mathrm{C} 33$ inoculant generated a higher concentration of acetic and propionic acids providing better aerobic stability after exposure to air.

\section{References}

Abdel-Rahman, M. A., Tashiro, Y., \& Sonomoto, K. (2011). Lactic acid production from lignocellulose-derived sugars using lactic acid bacteria: overview and limits. Journal of Biotechnology, 156(4), 286-301. doi: 10.1016/j.jbiotec.2011.06.017
Borreani, G., Tabacco, E., Schmidt, R. J., Holmes, B. J., \& Muck, R. E. (2018). Silage review: factors affecting dry matter and quality losses in silages. Journal of Dairy Science, 101(5), 3952-3979. doi: 10.3168/ jds.2017-13837

Filya, I., \& Sucu, E. (2010). The effects of lactic acid bacteria on the fermentation, aerobic stability and nutritive value of maize silage. Grass and Forage Science, 65(4), 446-455. doi: 10.1111/j.1365-2494. 2010.00763.x

Fugita, C. A., Prado, I. N. D., Jobim, C.C.,Zawadzki, F., Valero, M. V., Pires, M. C. D. O.,... Françozo, M. C. (2012). Silagem de milho com e sem inoculantes enzimáticos-bacterianos sobre desempenho, características da carcaça e qualidade da carne em touros terminados em confinamento. Revista Brasileira de Zootecnia, 41(1), 154-163. doi: 10.1590/S1516-35982012000100023

Holzer, M., Mayrhuber, E., Danner, H., \& Braun, R. (2003). O papel de Lactobacillus buchneri na preservação de forragens. Tendências em Biotecnologia, 21(6), 282-287. doi: 10.1016/S0167-7799(03) 00106-9

Jobim, C. C., \& Nussio, L. G. (2013). Princípios básicos da fermentação na ensilagem. In R. A. Reis, T. F. Bernardes, \& G. R. Siqueira (Eds.), Forragicultura: ciência, tecnologia e gestão de recursos forrageiros (pp. 649660). Jaboticabal, SP: Multipress.

Kleinschmit, D. H., \& Kung, L., Jr. (2006). A metaanalysis of the effects of Lactobacillus buchneri on the fermentation and aerobic stability of corn and grass and small-grain silages. Journal of Milk Science, 89(10), 4005-4013. doi: 10.3168/jds.S00220302(06)72444-4

Li, Y., \& Nishino, N. (2011). Monitoring the bacterial community of maize silage stored in a bunker silo inoculated with Enterococcus faecium, Lactobacillus 
plantarum and Lactobacillus buchneri. Journal of Applied Microbiology, 110(6), 1561-1570. doi: 10.1111/j.13652672.2011.05010.x

Lynch, J. P., Baah, J., \& Beauchemin, D. K. A. (2015). Conservation, fiber digestibility, and nutritive value of corn harvested at 2 cutting heights and ensiledwith fibrolytic enzymes, either alone or with a ferulic acid esterase-producing inoculant. Journal of Dairy Science, 98(2), 1214-1224. doi: 10.3168/jds.2014-8768

Montes, F., Hafner, S. D., Rotz, C. A., \& Mitloehner, F. M. (2010). Temperature and air velocity effects on ethanol emission from corn silage with the characteristics of an exposed silo face. Atmospheric environment, 44(16), 1987-1995. doi: 10.1016/j.atmosenv.2010.02.037

Moon, N. J. (1983). Inhibition of the growth of acid tolerant yeasts by acetate, lactate and propionate and their synergistic mixtures. Jornal de Bacteriologia Aplicada, 55(3), 453-460. doi: 10.1111/j.1365-2672. 1983. tb01685.x

Muck, R. E. (2010). Silage microbiology and its control through additives. Revista Brasileira de Zootecnia, 39(3), 183-191. doi: 10.1590/S1516-35982010001300021

Oliveira, A. S., Weinberg, Z. G., Ogunade, I. M., Cervantes, A. A., Arriola, K. G., Jiang, Y.,... Adesogan, A. T. (2017). Metaanalysis of effects of inoculation with homofermentative and facultative heterofermentative lactic acid bacteria on silage fermentation, aerobic stability, and the performance of dairy cows. Journal of Dairy Science, 100(6), 4587-4603. doi: 10.3168/jds.2016-11815

Oliveira, M. R., Neumann, M., Oliboni, R., Gobetti, S. T. C., \& Faria, M. V. (2011). Use of biological addictive in ensiling of forage.
Ambiência, 7(3), 589-601. doi: 10.5777/ ambiencia. 2011.03.01rb

Oney, C. R., Gramkow, J. L., Watson, A. K., Erickson, G. E., McDonald, J. C., \& Biddlecome, M. K. (2018). The effect of inoculants on nutrient losses of corn silage and high-moisture corn stored in mini silo. Nebraska Beef Cattle Report, 968, 63-66.

Price, J. D. A. (1969). Modification of the barker -summerson method for the determination of lactic acid. Afialyst, 94, 1151-1152.

Rabelo, A. H. S., Rezende, A. V., Nogueira, D. A., Rabelo, F. H. S., Senedese, S. S., Vieira, P. F.,... Carvalho, A. (2012). Perdas fermentativas e estabilidade aeróbia de silagens de milho inoculadas com bactérias ácido-láticas em diferentes estádios de maturidade. Revista Brasileira de Saúde e Produção Animal, 13(3), 656-668. doi: 10.1590/ S1519-99402012000300006

Rodrigues, P. H. M., Pinedo, L. A., Marino, C. T., Meyer, P. M., Borgatti, L. M. O., \& Franco, F. M. J. (2015). Efeitos de inoculantes microbianos e subprodutos da produção de aminoácidos na fermentação, composição química e estabilidade aeróbica da silagem de milho. Archivos de Zootecnia, 64(246), 131-137.

Sá, A. D. Neto, Nussio, L. G., Zopollatto, M., Junges, D., \& Bispo, Á. W. (2013). Silagem de milho ou de cana-de-açúcar com Lactobacillus buchneri exclusivamente ou em associação com L. plantarum. Pesquisa Agropecuária Brasileira, 48(5), 528-535. doi: 10.1590/S0100204X2013000500009

SAS Institute.SAS/STAT user's guide:Statistics, version 6. (4a ed.). North Caroline, 1993. v. 2.

Silva, D. J., \& Queiroz, A. D. (2009). Análise de alimentos, métodos químicos e biológicos (4ª imp.). Viçosa, MG: UFV. 
Silva, M. S. J., Jobim, C. C., Poppi, E. C., Tres, T. T., \& Osmari, M. P. (2015) Production technology and quality of corn silage for feeding dairy cattle in Southern Brazil. Revista Brasileira de Zootecnia, 44(9), 303-313. doi: 10.1590/S180692902015000900001

Tabacco, E., Piano, S., Revello-Chion, A., \& Borreani, G. (2011). Effect of Lactobacillus buchneri LN4637 and Lactobacillus buchneri LN40177 on the aerobic stability, fermentation products, and microbial populations of corn silage under farm conditions. Journal of Dairy Science, 94(11), 5589-5598. doi: 10. 3168/ jds.2011-4286

Valeriano, A. R., Pinto, J. C., Ávila, C. L. D. S., Evangelista, A. R., Tavares, V. B., \& Schwan, R. F. (2009). Efeito da adição de Lactobacillus sp. na ensilagem de canade-açúcar. Revista Brasileira de Zootecnia, 38(6), 1009-1017. doi: 10.1590/S151635982009000600006

Weinberg, Z. G., Shatz, O., Chen, Y., Yosef, E., Nikbahat, M., Ben-Ghedalia, D., \& Miron, J. (2007). Effect of lactic acid bacteria inoculants on in vitro digestibility of wheat and corn silages. Journal of Dairy Science, 90(10), 4754-4762. doi: 10.3168/ jds.2007-0176
Wilkinson, J. M., \& Davies, D. R. (2013). The aerobic stability of silage: key findings and recent developments. Grass and Forage Science, 68(1), 1-19. doi: 10.1111/j.13652494.2012.00891.x

Zanette, P. M., Neumann, M., Faria, M. V., Ueno, R. K., Marafon, F., \& Durman, T. (2012). Valor nutricional e perdas durante a fermentação de silagens de milho (Zea mays) com açúcar ou inoculante. Revista Brasileira de Milho e Sorgo, 11(2), 178189. doi: 10.18512/1980-6477/rbms. v11n2p178-189

Zopollatto, M., Nussio, L. G., Mari, L. J., Schmidt, P., Duarte, A. P., \& Mourão, G. B. (2009). Alterações na composição morfológica em função do estádio de maturação em cultivares de milho para produção de silagem. Revista Brasileira de Zootecnia, 38(3), 452-461. doi: 10.1590/S151635982009000300008 
